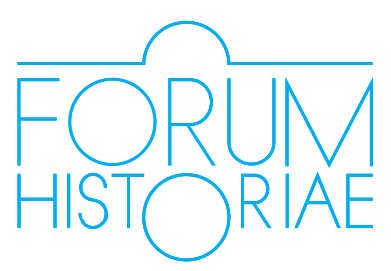

\title{
Sicherheitsdienst a autonómne Slovensko. Príklad Wernera Göttscha*
}

\author{
Michal Schvarc
}

\begin{abstract}
:
SCHVARC, Michal: Sicherheistdienst and the Autonomous Slovakia. A Biographical Sketch of Werner Göttsch

The subject of the study is a brief assessment of the operations of the SS Secret Service - Sicherheitsdienst (SD) in Slovakia during the period of autonomy (October 1938-March 1939), how it interfered with the internal political process and how it was instrumental in Slovak secession and the Nazi plans for the post-Munich Czechoslovakia. The second part of the study is devoted to Werner Göttsch, a member of the "Amt III Ausland" SD, who played a relatively important role in promoting the German scheme in Slovakia in the first quarter of 1939. The author applies the methodological approach of the sub-discipline of holocaust research, the "neuere Täterforschung".

Keywords: Sicherheitsdienst (SD), Werner Göttsch, Reinhard Heydrich, Slovak Secession, Vienna DOI: https://doi.org/10.31577/forhist.2019.13.1.2
\end{abstract}

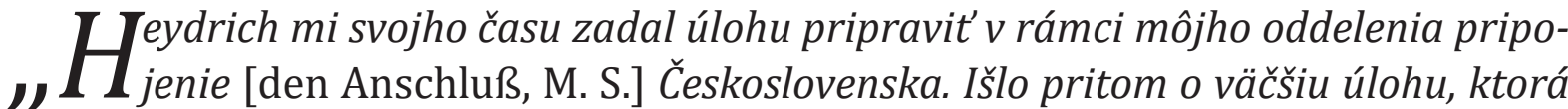
ma zamestnávala dlhší čas. Plánovali sme, že slovenská strana uskutoční povstanie, ktorého cielom bude odtrhnutie Slovenska. Za týmto účelom som sa dlhší čas zdržiaval vo Viedni, odkial' som často cestoval do Bratislavy, aby som nadviazal kontakt so slovenskými nacionalistami. ${ }^{.1}$

Uvedené slová patria Wernerovi Göttschovi, ktorý v júni 1974 odpovedal na otázku nemeckých vyšetrovatelov týkajúcu sa jeho roly počas likvidácie československého štátu na prelome rokov 1938/39. Tieto štyri vety v komprimovanej podobe v podstate korešpondujú s rozsiahlou 20-stranovou správou, ktorú W. Göttsch koncom marca 1939 zaslal svojmu vtedajšiemu najvyššiemu nadriadenému Reinhardovi Heydrichovi, šéfovi Bezpečnostnej polície a Bezpečnostnej služby. ${ }^{2}$

Problematike pôsobenia Bezpečnostnej služby ríšskeho vodcu SS - Sicherheitsdienst (SD) na Slovensku v rokoch 1938 - 1945 sa systematicky venujem už niekol'ko rokov. Ked’že som na túto tému publikoval viacero odborných textov, ${ }^{3}$

\footnotetext{
* Štúdia vznikla v rámci projektu VEGA č. 2/0110/16: Nábor a vojenská služba slovenských Nemcov vo Waffen-SS 1939 - 1945. Predpoklady, priebeh, zaradenie do jednotlivých formácií a trestno-právne dôsledky po roku 1945 a APVV-14-0644: Kontinuity a diskontinuity politických a spoločenských elít na Slovensku v 19. a 20. storočí.

1 Bundesarchiv (BArch) Ludwigsburg, B 162/20570, Bl. 2-13, Výsluch Wernera Göttscha 11. júna 1974.

2 Originál sa nachádza v archíve Institut für Zeitgeschichte Viedenskej univerzity pod inv. č. 397. Prepis správy bol publikovaný SCHRIFFL, David - SCHVARC, Michal. „Vec: Československo“. Neznáma správa Wernera Göttscha o okolnostiach vzniku Slovenského štátu. In Historický časopis, 2012, roč. 60, č. 1, s. 115-139.

3 SCHVARC, Michal. Organizácia nemeckej bezpečnostnej služby (Sicherheitsdienst - SD) na Slovensku od roku 1939 do vypuknutia SNP. In Vojenská história, 2005, roč. 9, č. 1, s. 41-55; SCHVARC, Michal (ed.)
} 
v prvej časti svojej štúdie sa obmedzím na stručný náčrt aktivít SD v autonómnej Slovenskej krajine, t. j. od októbra 1938 do polovice marca 1939. Pritom kladiem dôraz na doteraz ešte málo známe aspekty činnosti SD súvisiace najmä s deportáciou Židov na „územie nikoho“, teda do nového pohraničia stanoveného prvou Viedenskou arbitrážou na začiatku novembra 1938. V druhej časti štúdie vystupuje do popredia spomenutý W. Göttsch ako významný aktér procesu inštrumentalizácie slovenských nacionalistov do nacistických plánov likvidácie Česko-Slovenska 1938/39. Nesústred'ujem sa len na rolu, ktorú zohrával na Slovensku počas obdobia autonómie, ale pokúšam sa o jeho komplexnejšiu biografiu. Pri nej používam nástroje subdisciplíny výskumu holokaustu nazývanej v nemeckom jazykovom priestore „neuere Täterforschung“. Jej základ tvorí biografická metóda skúmajúca motívy konania jednotlivca, vplyv prostredia na formovanie osobnosti či eticko-morálne referenčné rámce. ${ }^{4}$ Hoci W. Göttsch nebol páchatelom šoa, domnievam sa, že metódy „neuere Täterforschung“ možno aplikovat’ aj v jeho prípade. Ako príklad uvádzam biografiu Alfreda Naujocksa nemeckého historika Floriana Altenhönera. ${ }^{5}$

Vyhlásenie autonómie okrem iného otváralo priestor na posilňovanie nemeckého vplyvu v Slovenskej krajine. Významnú úlohu v tomto procese zohrali nacistické tajné služby, predovšetkým Bezpečnostná služba ríšskeho vodcu SS - Sicherheitsdienst (SD). Blízkost' Viedne priam predurčovala na plnenie tejto misie tamojší „SD-Donau“.6 Lenže nebol by to R. Heydrich, keby zostal len pri jedinej opcii ${ }^{7}$ operatívneho rozpracovania Slovenska. Popri viedenskej SD do záležitosti zaangažoval aj Úrad III (zahraničie)/„Amt III Ausland“ SD, kam organizačne patril vyššie spomenutý W. Göttsch. Konkurenčné prostredie a tlak mali pôsobit' ako katalyzátor pri hl'adaní pokial' možno optimálnych modalít splnenia Heydrichovho rozkazu.

\footnotetext{
Sicherheitsdienst a Slovensko v rokoch 1938 - 1944 (Od autonómie po Povstanie). Slovenský štát vo vybraných správach SD od jesene 1943 do septembra 1944. Bratislava : SNM-Múzeưm kultúry karpatských Nemcov, 2006; SCHVARC, Michal. „Sicherheitsdienst“ a politický pád Ferdinanda Ďurčanského. In KMEŤ, Norbert SYRNÝ, Marek (eds.) Odval'ujem balvan. Pocta historickému remeslu Jozefa Jablonického. Banská Bystrica : Múzeum Slovenského národného povstania, 2013, s. 94-116; SCHVARC, Michal. Sicherheitsdienst a slovenská secesia 1938/1939. In ROGULOVÁ Jaroslava - HERTEL, Maroš et al. Adepti moci a úspechu. Etablovanie elít $v$ moderných dejinách. Jubileum Valeriána Bystrického. Bratislava : Veda, 2016, s. 287-302.

4 Pozri napr. PAUL, Gerhard - MALLMANN, Klaus-Michael. Sozialisation, Milieu und Gewalt. Fortschritte und Probleme der neueren Täterforschung. In MALLMANN, Klaus-Michael - GERHARD, Paul (eds.) Karrieren der Gewalt. Nationalsozialistische Täterbiographien. Darmstadt : WBG, 2004, s. 1-32; BAJOHR, Frank. Täterforschung: Ertrag, Probleme und Perspektiven eines Forschungsansatzes. In BAJOHR, Frank - LÖW, Andrea (eds.) Der Holocaust. Ergebnisse und neue Fragen der Forschung. Frankfurt am Main : Fischer Verlag, 2015, s. 167-185.

5 ALTENHÖNER, Florian. Der Mann, der den 2. Weltkrieg begann. Alfred Naujocks: Fälscher, Mörder, Terrorist. Münster : Prospero Verlag, 2010.

6 K úlohe viedenských nacistických úradovní pri podpore slovenskej secesie 1938/39 pozri SCHRIFFL, David. Die Rolle Wiens im Prozess der Staatswerdung der Slowakei 1938/39. Frankfurt am Main : Peter Lang, 2004.

7 HACHMEISTER, Lutz. Der Gegnerforscher. Die Karriere des SS-Führers Franz Alfred Six. München : Verlag C. H. Beck, 1998, s. 146; GERWARTH, Robert. Reinhard Heydrich. Biographie. München : Siedler Verlag, 2011, s. 99. Názorným príkladom ako R. Heydrich využíval rivalitu svojich podriadených na dosiahnutie svojich cielov je konflikt o koncepciu budúceho Hlavného úradu ríšskej bezpečnosti RSHA medzi Wernerom Bestom a Walterom Schellenbergom. Pozri HERBERT, Ulrich. Best. Biographische Studien über Radikalismus, Weltanschauung und Vernunft 1903 - 1989. Bonn : Verlag J. H. W. Dietz, 1996, s. 228-233; WILDT, Michael. Generation des Unbedingten. Das Führungskorps des Reichssicherheitshauptamtes. Hamburg : Hamburger Edition HIS, 2018, s. 259-276; PAEHLER, Katrin. The Third Reich's Intelligence Services: The Career of Walter Schellenberg. New York : Cambridge University Press, 2017, s. 49-76.
} 
Na začiatku roku 1938 prejavovala SD en bloc o Slovensko minimálny záujem. Po anexii Rakúska sa na tomto prístupe vela nezmenilo. Až v súvislosti s československou krízou v septembri 1938 a vnútropolitickými zmenami ČSR upriamili orgány podriadené Heydrichovi pozornost' aj na východnú čast' republiky. Predovšetkým viedenský „SD-Donau“ sa na Slovensku rýchlo etabloval. ${ }^{8}$ Nielenže sledoval politické dianie v krajine, ale mal ambíciu doň aj zasahovat'. Len mesiac po Heydrichovom príkaze sa náčelník „SD-Donau“ mohol v polovici októbra 1938 pochválit' „výbornými kontaktmi so slovenskou vládou“a s jej žiadostou o vyslanie expertov na slobodomurárske lóže, očistu verejných knižníc a „židovskú otázku“.9 Išlo skutočne o obratnost' pracovníkov viedenskej SD alebo len o naivnú dôverčivost' nových mocipánov v Bratislave v snahe získat' si nemeckú náklonnost' v súvislosti s premrštenými mad’arskými územnými požiadavkami? Vzhladom na útržkovitý pramenný materiál nie je vôbec jednoduché nájst’ odpovede na položené otázky. V každom prípade v „židovskej otázke“ slovenskej žiadosti „SD-Donau"vel'mi promptne vyhovel.

Ešte predtým, ako do Bratislavy začiatkom novembra 1938 prišiel Adolf Eichmann, stratégiu postupu preberal „SD-Donau“ s referátom II 112 berlínskeho ústredia Hlavného bezpečnostného úradu. Ten radil sledovat’ situáciu Židov, zhromažd'ovat' informácie a taktiež upozorňovat' slovenskú vládu „na nutnost' riešit' tento problém“ s tým, aby sa pokúšala „inscenovat' akcie l'udu proti Židom “10 Tieto inštrukcie boli vydané tesne pred vyhnaním približne 17-tisíc pol'ských Židov z Nemecka do Pol'ska a týždeň pred prvou Viedenskou arbitrážou.

Ked' 3. novembra A. Eichmann pricestoval do slovenskej metropoly, krajina a vedúci l'udácki politici sa len spamätávali zo šoku z Viedne. Napriek zdrvujúcemu arbitrážnemu výroku režim dokázal okamžite nájst' vinníkov za tento akt národného poníženia - Edvarda Beneša a najmä Židov. ${ }^{11}$ A proti Židom, konkrétne cudzím štátnym príslušníkom a osobám bez domovskej príslušnosti v Slovenskej krajine, pripravoval tvrdé protiopatrenie - deportáciu na územia, ktoré mali byt’ v zmysle prvej Viedenskej arbitráže odstúpené Mad’arsku. Eichmannova úloha, resp. úloha personálu „SD-Donau“ nie je v tejto záležitosti pre vel'mi torzovitú pramennú bázu jasná. Nepredpokladám však, že by A. Eichmann alebo muži z viedenskej SD sami boli iniciátormi akcie. Impulz vyšiel jednoznačne z prostredia autonómnej vlády a A. Eichmann mal skôr poradnú funkciu. ${ }^{12}$ Ako spiritus agens viedenskej Centrály pre židovské vystahovalectvo poskytol Slovákom s vel'kou pravdepodobnostou k dispozícii svoje doposial' nadobudnuté know-how; taktiež im mohol tlmočit' nemecké skúsenosti získané len niekol'ko dní predtým počas masového vyháňania

8 K aktivitám „SD-Donau“ pozri SCHVARC 2016, s. 289-295.

9 SCHVARC, Michal - HOLÁK, Martin - SCHRIFFL, David (eds.) „Tretia ríša“ a vznik Slovenského štátu. Dokumenty 1. Das „Dritte Reich“ und die Entstehung des Slowakischen Staates. Dokumente 1. Bratislava : Ústav pamäti národa, 2008, dokument č. 67, s. 172.

10 BArch Berlín, R 58/954, Bl. 161-165, Hagenova správa o ceste do Viedne 23. - 27. októbra 1938 z 31. októbra 1938.

11 KAMENEC, Ivan. Po stopách tragédie. Bratislava : Archa, 1991, s. 24-27.

$12 \mathrm{~K}$ Eichmannovmu pobytu v Bratislave a k jeho úlohe pri organizovaní deportácií pozri NIŽŇANSKÝ, Eduard. Židovská komunita na Slovensku medzi československou parlamentnou demokraciou a slovenským štátom v stredoeurópskom kontexte. Prešov : Universum, 1999, s. 36-45. 
Židov s pol'skou štátnou príslušnostou z Tretej ríše. ${ }^{13}$ Okrem toho A. Eichmann predostrel vládnym činitelom minimálne pät' návrhov zákonných opatrení namierených proti židovskému obyvatel'stvu, týkajúce sa napr. „príslušnosti $k$ židovskej rase", vytvorenia židovskej ústredne ako jediného predstavitela komunity, prihlasovania majetku, definovania židovských podnikov a dosadzovania nútených správcov do nich. Tieto návrhy, ako A. Eichmann vo svojom zázname z 8. novembra 1938 uvádza, boli predložené aj ministerskému predsedovi Jozefovi Tisovi. Ako však sklamane dodal, „pre intervenciu istých kruhov“ $\mathrm{k}$ ich schváleniu a následnému zverejneniu v úradných vestníkoch nedošlo. ${ }^{14}$

To je len jeden z príkladov zasahovania SD do vnútorných slovenských záležitostí. Ako d'alšiu oblast' možno uviest' Hlinkovu gardu. Jej vedúci funkcionári Karol Sidor a Karol Murgaš sa už prakticky od začiatku autonómie dostávali do myšlienkového vleku viedenskej SD. Predovšetkým K. Murgaš, vtedy náčelník politického štábu gardy, prakticky bezvýhradne prijímal odporúčania neoficiálneho poradcu organizácie z prostredia „SD-Donau“. Vo Viedni sa tak začalo vytvárat' zdanie, že celú HG možno inštrumentalizovat’ pre nacistické plány likvidácie teritoriálne oslabeného Česko-Slovenska. Stávka na K. Sidora a K. Murgaša sa však v konečnom dôsledku ukázala ako chybný krok, pretože obaja, no hlavne K. Sidor, v klúčových momentoch v tretej marcovej pentáde 1939 zlyhali. ${ }^{15} \mathrm{~K}$. Sidor po prevzatí premiérskej funkcie, ako je známe, odmietol na nemecký nátlak vyhlásit’ samostatnost'; K. Murgaš zase nedokázal zmobilizovat' gardu v takej miere, ako si to Viedeň predstavovala na inscenovanie „revolučných nálad“ v uliciach Bratislavy. ${ }^{16}$

Konkurenčný „Amt III Ausland“ si hladal iné cesty, ako sa dostat’ k l'udáckym politikom. Ako najschodnejšie sa ukazovalo napojenie na vodcu nemeckej menšiny Franza Karmasina, ktorého považoval za naslovovzatého znalca miestnych pomerov, ked'že na Slovensku pôsobil od roku 1926. Prostredníctvom F. Karmasina mohol W. Göttsch nadviazat' kontakty s Vojtechom Tukom. V. Tuka, odsúdený na jeseň 1929 na 15 rokov väzenia za vlastizradu, sa v novembri 1938 vrátil na Slovensko a začal propagovat' myšlienku vyhlásenia nezávislosti pod nemeckou gesciou. Kým „SD-Donau“ V. Tukovi príliš nedôveroval, pre W. Göttscha sa stal osobou, ktorá mala uskutočnit' spomínaný prevrat a proklamovat' nezávislost' v zmysle nacistických plánov. Prevrat sa neuskutočnil, ked'že V. Tuku už 10. marca 1939 internovala česko-slovenská kriminálna polícia. No na rozdiel od viedenskej konkurencie mal „Amt III Ausland“ vd’aka spolupráci s tieňovými štruktúrami ríšskeho ministerstva zahraničných vecí na Slovensku poruke záložný plán. Po zásahu ústrednej vlády v Prahe 9./10. marca začal favorizovat' J. Tisa ako hlavného kandidáta vyhlásenia štátu. Aj preto sa W. Göttsch významnou mierou podielal na organizovaní známej Tisovej audiencie u nemeckého diktátora večer 13. marca $1939 .{ }^{17}$

13 Kvyhnaniu pol'ských Židovz Nemecka pozri TOMASZEWSKI, Jerzy. Auftaktzur Vernichtung. Die Vertreibung der polnischen Juden aus Deutschland 1938. Osnabrück : Fibre, 2002.

14 BArch Berlín, R 70 Slowakei/37, Bl. 3, Eichmannov záznam o pobyte v Bratislave z 8. novembra 1938.

15 SCHVARC 2016, s. 292-294.

16 BYSTRICKÝ, Valerián. Zahraničnopolitické súvislosti vzniku Slovenského štátu 14. marca 1939. Bratislava : Veda, 2014, s. 387-391.

17 SCHVARC 2016, s. 297-301. Pozri tiež ALTENHÖNER, Florian. Der Auslandsnachrichtendienst des SD und 
Z konkurenčného zápasu dvoch zložiek SD vyšiel vít’azne teda „Amt III Ausland“. Hoci sa „Amt III Ausland“ nevyhol istým zaváhaniam, v konečnom dôsledku sa jeho koncept spolupráce s l'udáckymi politikmi osvedčil viac. A to aj napriek neustálym sporom s „SD-Donau“ a nie príliš vel'kej ochote „Amt III Ausland“ spolupracovat' na dosiahnutí spoločného ciela. Pre ambiciózneho viedenského šéfa Waltera Stahleckera, neskoršieho velitela „Einsatzgruppe A“, v okupovanom Sovietskom zväze zodpovedného za zavraždenie viac ako 240000 l'udí, prevažne židovských detí, žien a mužov (k 1. februáru 1942), ${ }^{18}$ to musela byt' trpká pilulka, ktorú potreboval strávit'. Čo však bolo podstatné, v Heydrichových očiach jeho povest' spolahlivého vykonávatel'a nacionálnosocialistického „nového poriadku“ neutrpela. V marci 1939 poveril W. Stahleckera vedením Einsatzgruppe II s miestom určenia na Morave a v júni ho vymenoval za velitela Sicherheitspolizei (Sipo) a SD v Protektoráte Čechy a Morava. Koncom apríla 1940 nasledovalo pôsobenie v okupovanom Nórsku ako velitel' Sipo a SD. Od polovice novembra 1940 do júna 1941 riadil propagandistické oddelenie $\mathrm{v}$ Ribbentropovom ministerstve zahraničných vecí (Auswärtiges Amt). Po smrti Hansa Nockemanna, ktorého R. Heydrich vybral pôvodne za velitel'a Einsatzgruppe A, prevzal ešte pred štartom operácie „Barbarossa" jeho uprázdnenú funkciu. ${ }^{19}$

Hoci aktivity Bezpečnostnej služby ríšskeho vodcu SS na autonómnom Slovensku sú vcelku dobre zmapované, personáliám príslušníkov SD nasadených pri procese likvidácie pomníchovskej republiky venovala slovenská historiografia doposial' minimálnu pozornost'. Z tohto dôvodu sa v druhej časti svojej sondy vrátim $\mathrm{k}$ už v úvode spomenutému W. Göttschovi. W. Göttsch v nacionálnosocialistickom pláne podpory slovenskej secesie zohral pomerne významnú úlohu. Nie náhodou sa preto ocitol na zozname osôb bratislavského ministerstva zahraničných vecí, „ktoré sa pri osamostatnení Slovenska mimoriadne vyznamenali“. ${ }^{20}$ Avšak jeho „zásluhy" pri zrode prvého satelitu Tretej ríše neboli napokon z neznámych dôvodov ocenené žiadnym z vyznamenaní nového štátu na mape strednej Európy. ${ }^{21}$

V marci 1939 patril vtedy ešte len 27-ročný W. Göttsch už medzi ostrielané kádre Heydrichovej SD. Rodák zo severonemeckého prístavného mesta Kiel pochádzal z rodiny stavebného majstra. ${ }^{22}$ Či sa však narodil a vyrastal $v$ dobrých sociálnych pomeroch, ako uvádza historik Florian Altenhöner, alebo v núdznych, ako tvrdil sám

die Erklärung der slowakischen Unabhängigkeit am 14. März 1939. In Zeitschrift für Geschichtswissenschaft, 2009 , roč. 57 , č. 10 , s. 811-832.

18 SCHUHLADEN-KRÄMMER, Jürgen. Die Exekutoren des Terrors. Hermann Mattheiß, Walter Stahlecker, Friedrich Mußgay, Leiter der Geheimen Staatspolizeistelle Stuttgart. In KISSENER, Michael - SCHOLTYSECK, Joachim (eds.) Die Führer der Provinz. NS-Biographien aus Baden und Württemberg. Konstanz : UVK, 1997, s. 430; BRÜGGEMANN, Sigrid. Walter Stahlecker. Chef der Gestapo in Stuttgart und Massenmörder. In ABMAYR, Hermann, G. (ed.) Stuttgarter NS-Täter. Vom Mitläufer bis zum Massenmörder. Stuttgart : Verlag Hermann G. Abmayr, 2009, s. 131.

19 SCHUHLADEN-KRÄMMER 1997, s. 426-428. Tiež KAŇÁK, Petr - VAJSKEBR, Jan. V prvním sledu. Kariéra velitele nacistických policejních jednotek Waltera Stahleckera. In Terezínské listy, 2015, roč. 43, s. 20-21.

20 Slovenský národný archív (SNA), fond (f.) Ministerstvo zahraničných vecí 1939 - 1945 (MZV), kartón (k.) 180, č. $7077 / 1940$.

21 BArch Berlín, ehem. BDC, SSO-Akte Werner Göttsch, SS-Stammkarte.

22 BArch Berlín, ehem. BDC, RuSHA-Akte Werner Göttsch, Životopis z 15. augusta 1938. 
W. Göttsch krátko po vojne pred americkými vyšetrovatel'mi, ${ }^{23}$ zostáva otázne. Jedno je isté, pre finančnú insolventnost' otca musel na konci roku 1931 ukončit' svoje štúdium na vysokej obchodnej škole. ${ }^{24} \mathrm{~V}$ tom čase Nemecko plnou silou zasiahla vel'ká hospodárska kríza a v podobnej situácii bez materiálneho zabezpečenia ako W. Göttsch sa ocitlo viac ako šest' miliónov obyvatel'ov krajiny. ${ }^{25}$ Jedným z dôsledkov hlbokej ekonomickej depresie bol nárast popularity extrémistických strán, hlavne Nacionálnosocialistickej robotníckej strany Nemecka (NSDAP). Kiel v tomto smere nepredstavoval žiadnu výnimku. Skôr naopak, tvoril jednu z bášt nacionálnych socialistov vo „Weimarskej republike“. V roku 1930 boli v Kieli druhým a o necelé dva roky neskôr už najsilnejším politickým zoskupením. ${ }^{26}$

Mladého W. Göttscha musel razantný nástup nacistov prit’ahovat'. Okrem toho mal aj svoj vzor, staršieho brata Helmutha, ktorý v decembri 1930 vstúpil do strany a o mesiac neskôr aj do SS. ${ }^{27}$ Werner krátko nato súrodenca nasledoval: v januári 1931 sa prihlásil do NSDAP a v polovici marca toho istého roku sa stal členom $\mathrm{SS}^{28}$ Po poldruha roku v kielskom SS, charakterizovanom množstvom pouličných bitiek s politickými odporcami a násilím vo všeobecnosti, ${ }^{29}$ prešiel W. Göttsch v októbri 1932 do SD. ${ }^{30} \mathrm{~V}$ tom čase išlo o pomerne bezvýznamnú zložku aparátu NSDAP, existujúcu len niečo vyše roka. Jej význam stúpol až po prevzatí moci nacionálnymi socialistami koncom januára 1933 a najmä po vyradení SA ako vnútropolitického mocenského faktora v lete 1934. Vtedy sa SD stala jedinou straníckou spravodajskou službou a šéf SS Heinrich Himmler ju koncom januára 1935 povýšil na jeden z hlavných úradov SS. ${ }^{31}$

Ruka v ruke s rastúcim vplyvom SD postupoval W. Göttsch v jej štruktúrach smerom nahor. Krátko po vstupe do SD sa na Heydrichov pokyn presunul do Berlína, kde sa podielal na budovaní organizácie SD-Oberabschnitt Ost pod vedením Hansa Kobelinskeho. ${ }^{32}$ W. Göttsch nebol jediným zo spolupracovníkov v počiatočnej fáze SD, kto pochádzal z Kielu. Nemecký historik Florian Altenhöner napočítal vyše 40 tzv. „kielskych kamarátov“, ktorí v rokoch 1932 - 1934 vstúpili do služieb SD. Zväčša išlo o mužov „generácie vojnových detí“ (Kriegsjugendgeneration). Vojnu zažili ako deti v zázemí a vyrastali s nespracovanou traumou porážky nemeckého cisárstva. Pochádzali z relatívne dobrých sociálnych pomerov a absolvovali

23 ALTENHÖNER 2010, s. 352. The National Archives Kew (TNA), KV 3/248, s. 3. Výsluch W. Göttscha 24. júla 1945. Za sprostredkovanie dokumentu d'akujem kolegovi Dušanovi Segešovi.

24 BArch Berlín, ehem. BDC, SSO-Akte Werner Göttsch, Životopis z 20. januára 1934. Landesarchiv (LA) Berlín, B Rep. 057-01, Nr. 1135, Bl. 28-31, Göttschov výsluch na Krajinskom kriminálnom úrade v Kieli 15. decembra 1964.

25 WEHLER, Hans-Ulrich. Deutsche Gesellschaftsgeschichte 1914 - 1949, Band 4. München : Verlag C. H. Beck, 2003, s. 259.

26 Dostupné na internete: http://www.akens.org/akens/texte/ak_ap/reader/wahlen.html.

27 BArch Berlín, ehem. BDC, SSO-Akte Helmuth Göttsch.

28 LA Berlín, B Rep. 057-01, Nr. 1135, Bl. 28, Návrh na Göttschovo povýšenie z 28. januára 1944. V životopise z augusta 1938 uvádza vstup do SS decembri 1930. Pozri BArch Berlín, ehem. BDC, RuSHA-Akte Werner Göttsch.

29 ALTENHÖNER 2010, s. 34.

30 LA Berlín, B Rep. 057-01, Nr. 1135, Bl. 17, Výt’ah z kmeňovej karty SS W. Göttscha.

31 WILDT 2018, s. 241-247.

32 TNA, KV 3/248, s. 3, Výsluch W. Göttscha 24. júla 1945. LA Berlín, B Rep. 057-01, Nr. 1135, Bl. 28-31, Göttschov výsluch na Krajinskom kriminálnom úrade v Kieli 15. decembra 1964. 
stredoškolské vzdelanie. Avšak hospodárska kríza im znemožnila uplatnenie na trhu práce, resp. pokračovat' vo vysokoškolskom štúdiu. Títo muži predstavovali pre SD vhodný typ aj z hladiska optimalizácie nákladov: väčšinou nemali manželské záväzky, nedisponovali akademickým vzdelaním a boli ochotní pracovat' za nižšiu mzdu. Socializácia v SS predstavovala dostatočnú záruku ich lojality. ${ }^{33}$

O necelé dva roky neskôr sa W. Göttsch prestahahoval do Mníchova. Popri riadení referátu „komunizmus a marxizmus“ plnil aj funkciu Heydrichovho pobočníka. Po prevzatí gestapa H. Himmlerom sa vrátil opät' do Berlína, kde nad'alej ako v bavorskej metropole viedol oddelenie „pre svetonázorové otázky“ ${ }^{34}$ Kariérny rast sa neprejavoval len vyššími funkciami v rámci SD, ale aj postupom v hodnostnom rebríčku SS. V júni 1934 bol povýšený za SS-Obersturmführera (ekvivalent hodnosti nadporučík) a koncom januára 1935 za SS-Hauptsturmführera (kapitán). To všetko vo veku necelých 23 rokov. ${ }^{35}$ Ďalší posun smerom nahor nezastavila ani Göttschova dopravná nehoda počas plnenia služobných úloh s následkom usmrtenia policajta v polovici mája $1935,{ }^{36}$ ani údajné nezhody so šéfom R. Heydrichom. K tým malo dôjst' niekedy na prelome rokov 1936/1937, ked' mal požiadat' o prepustenie z SD a na niekol'ko mesiacov organizáciu aj opustit'. Problémom však je, že ich uvádza len samotný W. Göttsch. ${ }^{37} \mathrm{~V}$ jeho osobnom spise dôstojníka SS sa žiadna takáto zmienka nenachádza. Naopak, v ostrom kontraste proti Göttschovmu tvrdeniu stojí Heydrichova úporná snaha o zmenu trestu na podmienečný, následne o zastavenie trestného stíhania proti podriadenému a napokon o výmaz z registra trestov. ${ }^{38}$ Proti hovorí tiež vyslanie W. Göttscha na kurz kriminálnych komisárov na policajnú školu v Berlíne-Charlottenburgu v októbri 1937, jeho úspešné absolvovanie a povýšenie do hodnosti SS-Sturmbannführera (major) na jeseň $1938 .^{39}$

Pravda, Göttschov kariérny postup neurčovala len lojalita k nadriadenému R. Heydrichovi. Rozhodujúcim kritériom bola úspešnost' realizácie špeciálnych úloh. Jednu z prvých predstavovala likvidácia Otta Strassera, niekdajšieho vrcholového funkcionára NSDAP, neskôr tvrdého Hitlerovho oponenta žijúceho v československom exile, resp. únos prevádzkovatela tajnej Strasserovej rozhlasovej stanice Rudolfa Formisa na prelome rokov 1934/1935. Hoci W. Göttsch spolu s A. Naujocksom R. Formisa neuniesli, ale zavraždili, šéf SD nemal

33 ALTENHÖNER 2010, s. 37-39.

34 TNA, KV 3/248, s. 3, Výsluch W. Göttscha 24. júla 1945. LA Berlín, B Rep. 057-01, Nr. 1135, Bl. 28-31, Göttschov výsluch na Krajinskom kriminálnom úrade v Kieli 15. decembra 1964. BArch Berlín, ehem. BDC, RuSHA-Akte Werner Göttsch, Životopis z 15. augusta 1938.

35 LA Berlín, B Rep. 057-01, Nr. 1135, Bl. 17, Výtah z kmeňovej karty SS W. Göttscha.

36 BArch Berlín, ehem. BDC, SSO-Akte Werner Göttsch, Prípis ríšskeho a pruského ministerstva vnútra H. Himmlerovi z 2. októbra 1935.

37 TNA, KV 3/248, s. 3, Výsluch W. Göttscha 24. júla 1945. LA Berlín, B Rep. 057-01, Nr. 1135, Bl. 28-31, Göttschov výsluch na Krajinskom kriminálnom úrade v Kieli 15. decembra 1964.

38 BArch Berlín, ehem. BDC, SSO-Akte Werner Göttsch, Heydrichov prípis hlavnému štátnemu zástupcovi pri okresnom súde v Kieli z 1. decembra 1936; Heydrichov list H. Himmlerovi z 21. augusta 1937; Heydrichov prípis hlavnému štátnemu zástupcovi pri okresnom súde v Kieli z 8. mája 1941.

39 BArch Berlín, ehem. BDC, RuSHA-Akte Werner Göttsch, Životopis z 15. augusta 1938. BArch Berlín, ehem. BDC, SSO-Akte Werner Göttsch, Hodnotiaca správa z 20. septembra 1938. 
dôvod na nespokojnost'. ${ }^{40}$ Nemenej významnou úlohou bolo tiež spravodajské rozpracovanie tzv. Spannovho kruhu, teda viedenského sociológa a teoretika koncepcie stavovského štátu Othmara Spanna, jeho najbližších spolupracovníkov a oddaných stúpencov. Krátko po „anšluse“ Rakúska viedol W. Göttsch špeciálne komando, ktoré zatklo O. Spanna a jeho syna Rafaela. Podla svojich vyjadrení ich mal pôvodne zastrelit', čo však z humánnych dôvodov odmietol vykonat'. Hoci to z Göttschových úst nevyznieva príliš vierohodne, jeho verziu potvrdil jeden z dotknutých - Rafael Spann. ${ }^{41}$ W. Göttsch mohol byt' na základe toho západonemeckými vyšetrovatel'mi zbavený prit’ažujúceho obvinenia.

Ďalšie poverenie osobitného významu prišlo na jeseň 1938 a malo prispiet' $\mathrm{k}$ destabilizácii už aj tak dost' labilného pomníchovského Česko-Slovenska. W. Göttsch v zmysle Heydrichových rozkazov zameral pozornost' na slovenskú čast' dožívajúcej republiky s cielom zakomponovat' separatistické tendencie časti l'udáckych politikov do nemeckých plánov. Za týmto účelom sa premiestnil do blízkej Viedne. Tu spoločne s Wilhelmom Waneckom, rodákom z rakúskeho hlavného mesta, aktívnym nacionálnym socialistom od roku 1931 a príslušníkom SD od jesene 1934, ${ }^{42}$ založili začiatkom roku 1939 „Blocksstelle“, ktorá slúžila na získavanie spravodajských kontaktov nielen na Slovensku, ale aj v d’alších krajinách dunajsko-karpatského priestoru. Odtial'to W. Göttsch pravidelne, od konca januára 1939 takmer každý deň, dochádzal do Bratislavy. ${ }^{43}$ Oboznamoval sa so situáciou a hladal vhodných kandidátov medzi l'udáckymi politikmi na zapriahnutie do nemeckých plánov, podporujúc ich snahy o vyhlásenie nezávislosti. Ako sprostredkovatel' mu poslúžil, ako som už uviedol, F. Karmasin, s ktorým sa musel spoznat' niekedy na prelome októbra/novembra $1938 .{ }^{44}$ Slovensko teda nebolo pre W. Göttscha až takým neznámym prostredím, ako sa to po vojne usiloval vsugerovat' americkým vyšetrovatelom.

Vd’aka F. Karmasinovi sa W. Göttsch na Slovensku rýchlo zorientoval. V polovici februára 1939, krátko po Tukovej návšteve v Berlíne u nemeckého diktátora, referoval ríšskemu ministrovi zahraničia o možnostiach uskutočnenia prevratu Tukovou skupinou. Okamžite po návrate z hlavného mesta ríše sa spolu s agentom Auswärtiges Amtu Edmundom Veesenmayerom ${ }^{45}$ zúčastnil schôdzky s l'udáckymi radikálmi, kde sa hovorilo o výhodách samostatnosti pod nemeckým patronátom. Koncom mesiaca opät' podával správu Joachimovi Ribbentropovi o stave príprav prevratu, určenom na 11 . marca. ${ }^{46} \mathrm{~K}$ nemu však zo známych príčin

40 ALTENHÖNER 2010, s. 71-85. Pozri tiež CÍLEK, Roman. Muž, jehož řemeslem byl zločin. Z historie nacistické špionáže. Praha : Nakladatelství Ostrov, 2016, s. 42-43.

41 HACHMEISTER, 1998, s. 17-18.

42 LA Berlín, B Rep. 057-01, Nr. 3197, Waneckov životopis z 28. septembra 1935.

43 TNA, KV 3/248, s. 7, Výsluch W. Göttscha 24. júla 1945. Národní archiv (NA) Praha, f. Ministerstvo vnitra Londýn, k. 119, 2-11-18a, s. 66. Prípis ministerstva národnej obrany ministerstvu vnútra z 31 . januára 1945 s prílohou, obsahujúcou informácie z výsluchu zajatého príslušníka SD. LA Berlín, B Rep. 057-01, Nr. 3197, Waneckov výsluch pred americkým vojenským tribunálom v Norimbergu 9. januára 1948.

44 BArch Koblenz, NL 1180/39, Nedatovaný (pravdepodobne december 1938) Rablov list bez uvedenia adresáta.

45 K Veesenmayerovej činnosti na Slovensku pozri MATIĆ, Igor-Philip. Edmund Veesenmayer. Agent und Diplomat der nationalsozialistischen Expansionspolitik. München : R. Oldenbourg Verlag, 2002, s. 61-79.

46 SCHRIFFL - SCHVARC 2012, s. 122-124. 
nedošlo. ${ }^{47}$ Göttschova misia sa týmto nezdarom nekončila. Naopak, sprevádzal Hitlerovho emisára Wilhelma Kepplera po príchode do Bratislavy a v noci z 12 . na 13. marca tlmočil zosadenému ministerskému predsedovi J. Tisovi verbálne pozvanie na rokovanie do Berlína k A. Hitlerovi. ${ }^{48} 0$ niekol'ko hodín neskôr sa spolu s A. Naujocksom podielál na koordinovaní fingovaných bombových útokov v Bratislave majúcich za ciel' vyvolat' ilúziu slovenskej revolúcie. ${ }^{49} \mathrm{~W}$. Göttsch teda pridelené úlohy splnil k plnej spokojnosti nadriadených. W. Keppler už o deň nato navrhol H. Himmlerovi jeho povýšenie. Šéf SS to odmietol s poukázaním na Göttschov mladý vek, postavenie v hierarchii SD a len nedávne udelenie hodnosti SS-Sturmbannführer. ${ }^{50}$ Napriek Himmlerovmu negatívnemu personálnemu rozhodnutiu mohol „Amt III Ausland“ SD prezentovat’ svoje aktivity vedúce k likvidácii Česko-Slovenska ako úspech. ${ }^{51}$

Po splnení úlohy v Bratislave sa W. Göttsch vrátil do Berlína. Či sa aj on zapojil do internej debaty o podobe budúceho Hlavného úradu ríšskej bezpečnosti (RSHA), je otázne. V auguste 1939, krátko pred napadnutím Pol'ska, dostal od R. Heydricha rozkaz odíst' do sliezskeho Vroclavu a skontrolovat' štádium príprav vyvolávania incidentov na tomto úseku nemecko-pol'skej hranice. ${ }^{52}$ Podla vlastného tvrdenia z polovice 70 . rokov sa po dvoch dňoch vrátil spät' do Berlína. ${ }^{53}$ W. Göttsch akúkolvvek účast' na fingovanom prepadnutí vysielača v Gliwiciach (Gleiwitz) kategoricky poprel, čo napokon potvrdil historik Florian Altenhöner v Naujocksovej biografii. ${ }^{54}$ Ináč to bolo v prípade únosu britských spravodajských dôstojníkov v holandskom pohraničnom meste Venlo. ${ }^{55}$ W. Göttsch sa nielen na akcii podiel'al, ale v prestrelke pravdepodobne smrtel'ne zranil holandského spravodajského dôstojníka Dirka Klopa. Podobne ako ostatní účastníci únosu dostal W. Göttsch priamo od A. Hitlera Železný kríž I. triedy. ${ }^{56}$

Po vzniku RSHA koncom septembra 1939 sa W. Göttsch stal vedúcim referátu VI D Juhovýchod. Do jeho kompetencie patrilo spravodajské pokrytie krajín dunajsko-karpatského priestoru a Balkánskeho polostrova vrátane Slovenska. ${ }^{57}$ W. Göttsch mal spolupracovat' na tomto poverení s mimoriadnym vyslancom ministra zahraničia pre otázky spravodajských služieb Manfredom von Killingerom, ${ }^{58}$ neskorším

47 Podrobnejšie BYSTRICKÝ 2014, s. 353-373.

48 SCHRIFFL - SCHVARC 2012, s. 128-129.

49 ALTENHÖNER 2010, s. 97-98.

50 BArch Berlín, NS 19/809, Bl. 41-42, 44, Korešpondencia medzi W. Kepplerom a H. Himmlerom 15. a 28. marca 1939.

51 ALTENHÖNER 2010, s. 102-103. Tiež Institut für Zeitgeschichte München (IfZ), MA 1563/26, NG-2316, Záznam o nasadení SD v zahraničí z 8. augusta 1940 a Politisches Archiv des Auswärtigen Amtes Berlín (PAAA), R 100741, Lutherov prípis vyslancovi Rintelenovi vo veci vyznamenania Heinza Josta z 26. augusta 1941.

52 TNA, KV 3/248, s. 3, 8, Výsluch W. Göttscha 24. júla 1945.

53 BArch Ludwigsburg, B 162/20570, Bl. 2-13, Výsluch Wernera Göttscha 11. júna 1974.

54 ALTENHÖNER 2010, s. 104-122.

55 K incidentu vo Venlo pozri podrobnejšie CÍLEK 2016, s. 192-246; ALTENHÖNER 2010, s. 104-122.

56 CÍLEK 2016, s. 246; ALTENHÖNER 2010, s. 130.

57 BArch Berlín, DP 3/1845, Organizačný plán RSHA z 1. februára 1940. PAAA, R 100750, Prípis náčelníka Bezpečnostnej polície a SD Auswärtiges Amt zo 6. februára 1940.

58 Der Bundesbeauftragte für die Unterlagen des Staatssicherheitsdienstes der ehemaligen Deutschen Demokratischen Republik (BStU), Ministerium für Staatssicherheit (MfS), HA IX/11, ZR 920/62, Bl. 42, 
šéfom nemeckej diplomatickej misie v Bratislave. Úlohu už však nestihol zrealizovat'. Na jar 1940 lekári diagnostikovali W. Göttschovi tuberkulózu. ${ }^{59}$ Sl'ubne vyvíjajúcu sa kariéru zastavila na dva roky zákerná choroba. Počas nich sa W. Göttsch zotavoval vo viacerých sanatóriách, okrem iného aj v Tatranskej Polianke. ${ }^{60}$

Po rekonvalescencii sa v lete alebo na jeseň 1942 vrátil do RSHA. Najprv pôsobil ako styčný dôstojník Úradu VI RSHA na ministerstve propagandy, kde sa podla vlastných slov prvýkrát dozvedel o „konečnom riešení židovskej otázky“61 Po prevzatí RSHA Ernstom Kaltenbrunnerom v roku 1943 sa W. Göttsch stal členom jeho štábu. Na jeseň 1943 bol preložený k úradnej skupine VI E so sídlom vo Viedni, ktorú viedol Göttschov starý známy W. Waneck. ${ }^{62}$ Tu sa mal na Kaltenbrunnerov príkaz, ako uviedol pri výsluchu v decembri 1964, pokúsit' nadviazat' kontakty s nepriatel'skými spravodajskými službami. Dôvod bol však ovela prozaickejší: Göttschova úloha spočívala v infiltrovaní sa do konzervatívnych skupín rakúskeho odboja. ${ }^{63}$ To mu umožnilo či už bezprostredne po vojne, alebo neskôr v Nemeckej spolkovej republike vydávat' sa za sympatizanta katolíckeho spektra rakúskeho odbojového hnutia a odporcu nacionálnosocialistického režimu. ${ }^{64}$ Povýšenie do hodnosti SS-Obersturmbannführera (podplukovník) v lete 1944 iniciované E. Kaltenbrunnerom ${ }^{65}$ svedčí o úplnom opaku a o pretrvávajúcej oddanosti k Tretej ríši.

Záver vojny zastihol W. Göttscha v Rakúsku v blízkosti šéfa RSHA E. Kaltenbrunnera. Spolu s kolegami W. Waneckom a Wilhelmom Höttlom sa cez svoje kontakty na rakúsky odboj usilovali spojit' zo západnými spojencami a rokovat’ s nimi o separátnom mieri pre Rakúsko. Naivne verili, že Anglo-Američania pristanú na ich argumentáciu s Rakúskom ako antikomunistickým nárazníkovým štátom, pričom počítali s účast’ou nacionálnych socialistov v prechodnej vláde. ${ }^{66}$ Po stroskotaní týchto sondáží sa W. Göttsch stiahol s Kaltenbrunnerovou suitou začiatkom mája 1945 do štajerského kúpel'ného mestečka Altaussee. 011 dní neskôr padol do amerického zajatia. ${ }^{67}$ Začalo sa pre neho pät'ročné obdobie internácie v amerických a francúzskych táboroch.

V júli 1945 absolvoval W. Göttsch dva intenzívne výsluchy. Prvý, uskutočnený začiatkom júla, sa týkal pokusov o nadviazanie kontaktov so západnými spravodajskými

$\overline{\text { Jostov záznam zo }}$ 6. marca 1940. BArch Ludwigsburg, B 162/20570, Bl. 2-13, Výsluch Wernera Göttscha 11. júna 1974.

59 BArch Ludwigsburg, B 162/20570, Bl. 2-13, Výsluch Wernera Göttscha 11. júna 1974. Porovnaj LA Berlín, B Rep. 057-01, Nr. 1135, Bl. 28-31, Göttschov výsluch na Krajinskom kriminálnom úrade v Kieli 15. decembra 1964.

60 BArch Ludwigsburg, B 162/20570, Bl. 2-13, Výsluch Wernera Göttscha 11. júna 1974.

61 Tamže.

62 WILDT 2018, s. 404-405.

63 ALTENHÖNER 2010, s. 226.

64 TNA, KV 3/248, s. 13-14, Výsluch W. Göttscha 24. júla 1945. BArch Ludwigsburg, B 162/20570, Bl. 2-13,Výsluch Wernera Göttscha 11. júna 1974.

65 LA Berlín, B Rep. 057-01, Nr. 1135, Bl. 15-16, Záznam Úradu I RSHA z 28. januára 1944; dekrét o povýšení podpísaný H. Himmlerom z 22. júla 1944.

66 BLACK, Peter. Ernst Kaltenbrunner. Vasall Himmlers: Eine SS-Karriere. Paderborn : Schöningh, 1991, s. 239-281.

67 TNA, KV 3/248, s. 2.,Výsluch W. Göttscha 24. júla 1945. 
službami na sklonku vojny. ${ }^{68} \mathrm{~V}$ druhom, 24. júla, sa americkí vyšetrovatelia zamerali na zostavenie Göttschovho profilu. Zaujímala ich Göttschova kariéra v SD, resp. v RSHA a najmä osobitné poverenia nariadené R. Heydrichom. Vyšetrovatelia sa pýtali na okolnosti zavraždenia R. Formisa, sudetskú krízu, prípad Venlo, aktivity úradnej skupiny RSHA VI E. Reč prišla pochopitel'ne aj na jeho poslanie na Slovensku. W. Göttsch uviedol nevyhnutné minimum a odpovedal tak, aby si žiadnym spôsobom neprit’ažil. ${ }^{69} \mathrm{~V}$ d’alších vypočúvaniach sa Američania sústredili hlavne na únos britských spravodajských dôstojníkov. Avšak z W. Göttscha nedostali nič zásadného, čo by mohlo viest' k vzneseniu obžaloby a postaveniu pred vojenský súd. Napriek tomu bývalý príslušník SD zostal až do konca roku 1948 v americkom zajatí. Na slobodu sa však ešte nedostal. Američania ho na prelome rokov 1948/1949 odovzdali Francúzom. Tí ho spravodajsky vytažovali v tirolskej metropole Innsbruck až do konca roku 1950. ${ }^{70}$

Po prepustení z internácie sa W. Göttsch vrátil do svojho rodného mesta. V Kieli v roku 1951 prešiel denacifikačným procesom. Hlavný denacifikačný výbor krajiny Šlezvicko-Holštajnsko ho zaradil do skupiny IV (Mitläufer) ${ }^{71}$ teda do kategórie minimálne zatažených nacistickou minulostou. Vzhl'adom na svoje niekdajšie postavenie nemožno záverečný súd úradu vnímat' inak ako frašku. Rozhodnutie výboru mu umožnilo zaradit' sa bezproblémovo do spoločnosti. W. Göttsch sa zamestnal ako obchodník/predavač, od roku 1956 pracoval ako účtovník v krajinskom zväze úverových družstiev. V druhej polovici 60. rokov zarábal mesačne 1400 DM, čo predstavovalo viac ako priemernú mzdu vo vtedajšom západnom Nemecku. Z platu si mohol dovolit' dovolenky v Rakúsku, Taliansku či Španielsku. $^{72}$ Okrem toho ešte dostával mesačne 150 DM ako agent CIA za informácie zvnútra krajne pravicovej Nationaldemokratische Partei Deutschlands (NPD). ${ }^{73}$

Napriek relatívne dobrému materiálnemu zabezpečeniu začínala v 60. rokoch W. Göttscha predsa len dobiehat’ vlastná hnedá minulost'. Ako obvinený bol vypočúvaný $\mathrm{v}$ prípade fingovaného prepadu rozhlasového vysielača v Gliwiciach a vraždy R. Formisa. Vyšetrovatelia ho predvolali tiež počas rozsiahleho vyšetrovania proti niekdajším pracovníkom RSHA. ${ }^{74}$ Ani jedno zo stíhaní napokon neviedlo k vzneseniu obžaloby a súdnemu stíhaniu. Platilo to aj v prípade zavraždenia pracovníka nemeckej ambasády vo Viedni Wilhelma von Kettelera,

68 Správa z výsluchu W. Göttscha zo 4. júla 1945. Dostupné na internete: https://www.cia.gov/library/ readingroom/docs/PAEFFGEN\%2C\%20THEODOR_0007.pdf.

69 TNA, KV 3/248, s. 1-16, Výsluch W. Göttscha 24. júla 1945.

70 BArch Ludwigsburg, B 162/20569, Bl. 25-35, Výsluch Wernera Göttscha 11. mája 1965. Záznam CIA zo 16. októbra 1967. Dostupné na internete: https://www.cia.gov/library/readingroom/docs/GOETTSCH\%2C\%20 WERNER_0034.pdf.

71 LA Berlín, B Rep. 057-01, Nr. 1135, Bl. 25, Rozhodnutie Hlavného denacifikačného výboru krajiny Schleswig-Holstein z 20. júna 1951.

72 Záznam CIA z 18. decembra 1968. Dostupné na internete: https://www.cia.gov/library/readingroom/ docs/GOETTSCH\%2C\%20WERNER_0055.pdf.

73 Záznam CIA z 15. januára 1969. Dostupné na internete: https://www.cia.gov/library/readingroom/ docs/GOETTSCH\%2C\%20WERNER_0055.pdf.

74 K stíhaniu bývalých príslušníkov RSHA západoberlínskym generálnym štátnym zastupitel'stvom pozri WEINKE, Annette. Amnestie für Schreibtischtäter. Das verhinderte Verfahren gegen die Bediensteten des Reichssicherheitshauptamtes. In MALLMANN, Klaus-Michael - ANGRICK, Andrej (eds.) Die Gestapo nach 1945. Konflikte, Karrieren, Konstruktionen. Darmstadt : WBG, 2009, s. 200-220. 
známeho odporcu nacionálnosocialistického režimu, na jar 1938. Stíhanie bolo v polovici 70. rokov zastavené. W. Göttsch si mohol užívat' pokojný dôchodok v rodnom Kieli, kde v roku 1983 zomrel. $^{75}$

Pôsobenie Bezpečnostnej služby SS na autonómnom Slovensku charakterizuje dvojkolajnost' a najmä tvrdý boj oboch navzájom si konkurujúcich zložiek jednej a tej istej organizácie. Dôsledkom toho bolo nejednotné posudzovanie pomerov a diania v krajine a protežovanie odlišných l'udáckych kandidátov na realizáciu nacistického scenára rozbitia dožívajúceho pomníchovského Česko-Slovenska. Každá zo zložiek SD ukázala pri meniacej sa situácii rôznu mieru flexibility. „Amt III Ausland“, prítomný na Slovensku predovšetkým cez osobu W. Göttscha, dokázal reagovat' na nečakané zmeny pružnejšie a aj preto vyšiel zo zápasu s viedenským „SD-Donau“ lepšie. W. Göttsch mal predsa len väčšie skúsenosti s prácou v zahraničí ako Stahleckerovi muži a nemal, na rozdiel od „SD-Donau“, ani ambíciu robit' v Bratislave vlastnú politiku.

W. Göttsch predstavuje prototyp prvej generácie príslušníkov SD, socializovanej v násilnom milieu SS začiatku 30. rokov a odhodlanej k plneniu špecifických úloh. Neskôr síce ustúpila do úzadia na úkor akademikov z "generácie neúprosných“, ale ako R. Heydrich, tak aj jeho nasledovník na čele RSHA E. Kaltenbrunner sa jej služieb úplne nezriekli. Svedčí o tom kariéra W. Göttscha. Išlo o presvedčeného nacionálneho socialistu, oddane slúžiacemu režimu až do jeho konca. Ak by ho z profesijného života nevyradila zákerná choroba, W. Göttsch by s vel'kou pravdepodobnostou patril do pomerne úzkeho okruhu exekútorov nacionálnosocialistického „nového poriadku“ na okupovaných územiach Sovietskeho zväzu. Z dostupných prameňov, s výnimkou nie príliš dôveryhodných vyjadrení počas výsluchu v júni 1974, nie je možné zrekonštruovat' Göttschov postoj k antisemitskej politike režimu a k samotnej fyzickej likvidácii Židov. Ako príslušník SS/SD s ňou podla všetkého súhlasil a príkaz špičiek režimu k masovému vraždeniu neodsudzoval, vnímal ju ako nevyhnutnost' na dosiahnutie vítazstva vo vojne a zabezpečenia budúcnosti nemeckého národa. Samozrejme, že pred justičnými orgánmi, či už pred spojeneckými alebo neskôr pred západonemeckými, svoje skutočné postoje z obáv o svoj osud zamlčiaval, resp. dával najavo vnútorné dištancovanie od spáchanej genocídy. To W. Göttschovi, podobne ako mnohým služobníkom nacionálneho socializmu a jeho režimu, pomohlo vyhnút' sa potrestaniu.

75 ALTENHÖNER 2010, s. 353.

Cituj:

SCHVARC, Michal. Sicherheitsdienst a autonómne Slovensko. Príklad Wernera Göttscha. In Forum Historiae, 2019, roč. 13, č. 1, s. 7-18. ISSN 1337-6861. DOI: https://doi.org/10.31577/forhist.2019.13.1.2

$\cdots$

PhDr. Michal Schvarc, PhD.

Oddelenie novších dejín

Historický ústav SAV,

P. O. Box 198, Klemensova 19,

81499 Bratislava

Slovenská republika

michal.schvarc@savba.sk 